\title{
The Role of Adaptive Environmental Management in Sustainable Development Case Study Assessing the Economical Benefits of Sustainable Construction in Greece
}

\author{
Odysseus G. Manoliadis \\ Democritus University of Thrace \\ Greece
}

\section{Introduction}

Recent public awareness of resources and its competing and conflicting use has prompted the sustainable development as a desired goal in the decision making process. The need for new approaches to sustainable management such as adaptive environmental management arises from the relatively new demands posed by the concept of sustainable development. The importance of information, integration and participation are necessary since science has changed to involve people more closely in research and development. Particular attention is paid to the challenges being posed for science as it seeks to more explicitly deal with the human dimension of sustainable management. The potential for adaptive management as an approach to more closely link research with management and policy is examined. Effective collaborative management requires different stakeholders associated with environmental problems to develop and enact solutions co-operatively, as opposed to acting as advocates purely in their own interest. However, because environmental issues are generally characterised by conflicting social perceptions, it is often difficult to ensure adequate stakeholder participation in developing and managing information to support collaborative decision making and subsequent change 'on-the-ground'. Everything has been said about development, but almost everything remains to be said and therefore to be explored or rediscovered, because incontestably, almost everything remains to be done. (Cosmao. 1984) Sustainable management issues continually change over time in response to co-evolving social, economic and ecological systems. Under these conditions adaptive management, offers an opportunity for more proactive and collaborative approaches to resolving environmental problems.

This research represents an inquiry into how an adaptive management that supports the concept of sustainable development can be initiated and implemented in complex, regional or large-scale contexts. An action research inquiry process is used to find improved ways of managing collaborative or multi-stakeholder approaches to environmental management, and to develop an integrated information framework to underpin subsequent decision making. The research involves one main case study economic assessment of sustainable construction. 
The main case study around which this research began with a research and development initiative in 2007 to address the problem of the economical benefits of sustainable construction in Greece (Manoliadis and Vatalis 2007). Consistent with an action research process, an initial framework for supporting a collaborative approach -a version of Delphi method approach - addressing this problem is outlined at the beginning of this study. What is significant about this case study is not that it has resulted in a regional adaptive management approach to assessing the economic benefit of sustainable construction but rather that those involved (researchers, managers and local government staff representatives) have learnt more about the issues involved, and continue to seek ways to resolve them within the framework of adaptive management.

One of the key characteristics of this approach is decision making and common action. The process that the researcher uses to guide those involved can be described as a spiral of action research cycles consisting of phases or the so called rounds. In this research these rounds can be seen to have taken place at a number of levels each involving different groups. The main group should be seen as the core research team involved in the implementation of the framework within the case studies described here. What follows is best regarded as an illustration of actions 'plan--act--reflect' using systems approach. This is, as Checkland (1981a,b;1985a,b,) points out, 'the best that can be hoped for, given the impossibility of capturing the actual richness of an intervention in human affairs'.

In the rest of this Chapter first background information about sustainability sustainable development and sustainable construction is presented. Then the research methodology based on adaptive management and Delphi method is analysed. The case study in terms of assessing the economic benefits of sustainable construction is following. Finally the results and conclusions of this research are presented together with proposals for further research.

\section{Background}

\subsection{Sustainability}

Sustainability is defined as the ability to carry forward or support or maintain for a prolonged period approaching perpetuity. Sustainability means meeting the needs of today without compromising the ability of future generations to meet their needs (Brundtland report, 1987). In business terms this is something that has traditionally been aspired to in terms of economic factors as businesses strive to balance inputs and outputs to maintain a profitable enterprise.

\subsection{Sustainable Development}

Sustainable Development has become a widely used term that goes beyond such economic security to include issues of environmental impact and sustainable use together with social effects. The triple bottom line created by this approach is what is now commonly meant when the term is used and this is the definition adopted. However, pressures are growing rapidly to adopt such an agenda and indeed to assess performance and report against such issues. Key business decisions are being increasingly taken with environmental and social concerns alongside economic ones as crucial parts of total value.

\subsection{Sustainable Construction}

The term sustainable construction was originally proposed to describe the responsibility of the construction industry for attaining sustainability. Kibert's definition of sustainable 
construction as “...creating a healthy built environment using sustainable-efficient, ecologically based principles". Hill and Bowen, 1997 divided Kibert's principles in four pillars: social, economic, biological and technical. Social sustainability highlights improvements in the quality of human life, and human living environment, which include culture, health, education, and intergenerational equity. Economic sustainability includes the use of full-cost accounting methods and real-cost pricing to set prices and tariffs for goods and services and achieve more efficient use of sustainable. Biological sustainability includes the motion that sustainable construction needs to protect the natural environment rather than pollute, encourages the use renewable sustainable and reduce the use of water, energy, materials and land in each stage of a project. Technical sustainability requires high performance, durability, quality and mixed use of a building (Hill and Bowen, 1997).

\section{Methodology}

The research methodology is based on Delphi method. Delphi concept was developed by the American defense industry. A project named Delphi was a study undertaken by the Rand Corporation for the US Air Force in the early 1950s (Helmer, 1966; Helmer 1970 Robinson, 1991). The Delphi method is a technique for obtaining forecasts from a panel of independent experts over two or more rounds. Experts are asked to predict quantities. After each round, an administrator provides an anonymous summary of the experts' forecasts and their reasons for them. When experts' forecasts have changed little between rounds, the process is stopped and the final round forecasts are combined by averaging. Delphi is based on well-researched principles and provides forecasts that are more accurate than those from unstructured groups (Rowe and Wright 1999).

The procedure was designed to obtain the most reliable consensus of opinion of a group of experts by a series of intensive questionnaires interspersed with controlled opinion feedback, and with the results of each round being fed into the next round (Linstone and Turoff 1975). This method involves the selection of procedures for suitable experts, development of appropriate questions to be put to them and analysis of their answers (Outhred 2001; Cabanis 2001). The desired outcome is that, by using such an iterative forecasting procedure, on reaching the final round the experts will have achieved unanimity on the issues put before them.

The main features of the Delphi method are: anonymity; iteration with controlled feedback; and statistical response (Dickey and Watts 1978; Adnan and Morledge 2003). Panel members remain unknown to one another and respond to a series of questionnaires. The iterative nature of the procedure allows them to modify their assessments and project them beyond their own subjective opinions. It can represent the best forecast available from consensus of experts (Corotis, et. al. 1981). The process is continued until a consensus is reached on the various issues under consideration, or until it becomes evident that no further consensus can be achieved. Generally, the number of rounds varies between two and seven while the number of participants ranges from three to fifteen (Rowe and Wright 1999; Adnan and Morledge 2003). The method involves posing a number of rounds (Figure 1) of appropriate questions on the specific subject area to a group of suitable pre-selected experts. Each one of the experts responds expressing his/her opinion and the collected results (answers) of this first stage are analyzed. 
These results are then collated and fed back to the respondents in an anonymous or nonattributable way, along with the second round questions. Each one of the participants is then able to take into account the opinions of the other participants when responding to the second round of questions. This process is then repeated for each subsequent round and, it is hoped, that by the final round a consensus of opinion on the issues put before them will have been reached. The process is typically carried out by remote correspondence, such as mailed questionnaires, rather than involving face-to-face group discussions. This enables all participants to respond individually and reduces the impact of group dynamics on the resulting consensus.

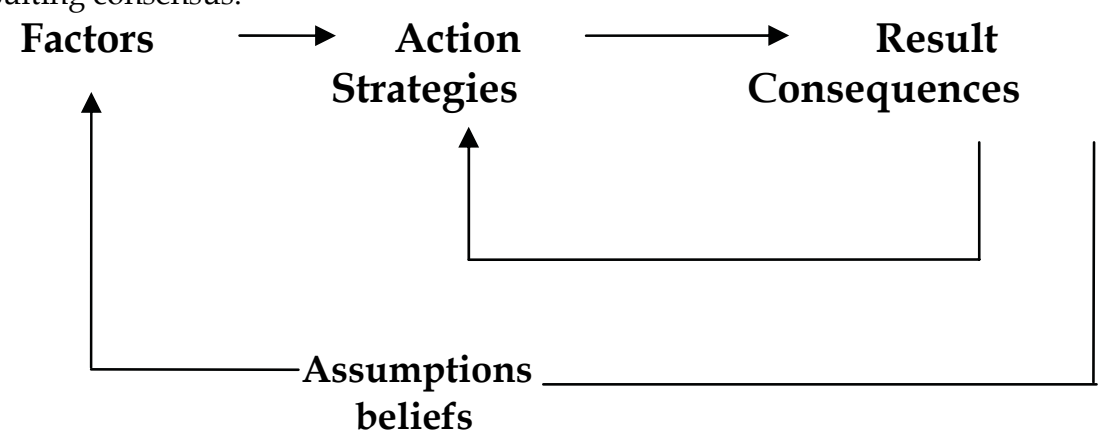

Fig. 1. The process of the proposed methodology

The method is based on the assumptions and beliefs of the selected experts, and does not rely on previous historical data being available. Moreover, the method is typically intended to provide a judgement or opinion on the specific subject area, rather then producing a quantifiable measure or result (Figure 1). Because of this, the method can easily work well in new areas which are frequently subject to unpredictable forces, which are not easily quantifiable in most of the cases. Another key factor is the anonymity of the participants, which permits them to express their opinions freely.

The major difficulties of Delphi, however, lie in maintaining the high level of response and in reaching and implementing a consensus. It is important that panel members treat the work seriously, devote the time necessary to provide thoughtful and reasoned responses to the questions and that they contribute to each round of Delphi. (Robinson, 1991).

\subsection{Preparation of the Delphi Study of the Greek Construction Industry}

The key issues in preparing the study are:

- The experts definition and selection

- the number of rounds and

- the questionnaire structure (i.e. number of questions) in each study round.

An expert may be defined as someone with special skills or knowledge evident through his or her leadership in professional organizations, or someone holding office in a professional organization, a presenter at national conventions or who has published in recognized journals (Cabanis 2002).

Once an expert panel has been identified, an additional problem is to maintain their input throughout the rounds of the study. The study is organized into a greater number of rounds in order to distil greater consensus of the participants and gain better forecasting accuracy. 
The Role of Adaptive Environmental Management in Sustainable Development

Moreover, the number of questions in each round is closely related to the time required from the participants to complete each round.

\section{Case Study}

\subsection{The Problem: Is Sustainable Construction More Economical?}

As sustainability issues enter in building construction the corresponding sustainability criteria are introduced in the building design. The organizations are empowered to accelerate the sustainable development; regulations both on national and local basis (Sha et al., 2000). Questions of economic assessment of the sustainable solutions have been arisen. For instance sustainably-designed buildings have such great economic benefits, in terms of the buildings life cycle then why more stakeholders aren't aware of them. The reason for this is likely due to the widely held belief that sustainable design costs more. This belief persists in spite of a growing body of research that point to numerous economic benefits from sustainably-designed buildings only in countries in which the construction is in decline. Many of the current examples in the private and public sector are often perceived as willing to take the initiative toward in strategic levels sustainable solutions without risk economic savings (Ofori, 1998).

Building occupiers, managers and others involved in making decisions on the maintenance and procurement of buildings are apt to adopt current best practice in their decision making through an improved understanding of the benefits that can be achieved through extra value to the value of inputs (Pearce, 2006). There is a perception amongst these groups that more sustainable solutions in maintenance and procurement inevitably result in increased capital costs and /or reduced market / staff appeal by adopting innovation in sustainable construction (Bossink, 2002; Manoliadis et al., 2006). They are interested firstly for the economic benefits of implementing sustainability solutions and secondly for environmental and social benefits. While experts on the topic claim that overall the economic assessment is to the sustainable solution's benefit no research has been made to substantiate the claim. The potential economic benefits may be difficult to see in the construction phase but there are returns of investment at the operation maintenance and the restoration phase. Each project has unique economics and a different performance and it's difficult to generalise that sustainable solutions through the life cycle will be economically viable project specific issues include site location, local conditions, national infrastructure taxes and fees, permit requirements.

It is actually a whole systems approach to design and implement that may influence the economics of the project in question. Since design is the first step to question if sustainable solutions will be applied without a overall study of the life cycle convincing stakeholders (owners operators public) is very hard attempt. The UK strategy on sustainable construction focuses 10 action points in order to achieve more sustainable construction. They are: the reuse of built assets, design for minimum waste, the aim of lean construction, minimizing energy in construction, minimizing energy in use, do not pollute, preserving and enhance biodiversity, conservation of water sustainables, the respect of people and their local environment and target setting (DETR, 1999).

The present trend in sustainable construction research focuses on the environmental and technical issues, via design and developing new technical, materials and components to achieve more efficient and better quality building. However, the achievement of marginal improvements in sustainable performance per unit of production will be made insignificant 
when compared to a higher future production rate (Uher, 1999). Therefore, it is essential to seek the economic principles of sustainable construction in order to create a profitable market for sustainable construction. Some concepts in the economic terms can be concluded in the below: Value for money, maximum output with minimum input, integration of short term return and long term benefits, stakeholder partnership between the demand and supply sides of the industry, business pattern changes from a linear process to a cyclic process (Khalfan et al, 2001).

\subsection{Sustainable Construction In Greece}

In Greece, the complex problems shared by cities are evidence of the impacts of urban sprawl: increasing traffic congestion and commuting times, air pollution, inefficient energy consumption, loss of open space and habitat, non-optimal allocation of economic sustainables and the loss of a sense of community. These combined pressures, along with the challenges faced specifically by stakeholders of the built environment, have led to a growing awareness of the need for change. In response to these pressures the concept of sustainability is beginning to permeate the Greece construction industry as a possible strategy to better meet the needs of clients and owners while ensuring business success in an increasingly competitive and constrained operational environment. While a variety of initiatives have been implemented to initiate the change toward increased sustainability, some critics have begun to realize that these initiatives are insufficient to bring about the change that is needed (Manoliadis and Vatalis 2007).

According to an extensive survey at the national level, the total annual energy consumption of buildings varies from $60-500 \mathrm{kWh} / \mathrm{m} 2$, depending on their utilization and type. More specifically, the annual energy consumption for heating varies between $30-170 \mathrm{kWh} / \mathrm{m} 2$; for cooling between 15-90 kWh/m2; for lighting between 10-50 kWh/m2; and for the operation of various appliances and equipment between $10-80 \mathrm{kWh} / \mathrm{m} 2$ (Bikas and Milonas, 1998).

Having this in mind a questionnaire survey was conducted to assess the economical benefits of sustainable construction in Greece. In doing so a questionnaire survey to Greek as well as other European Nationality respondents was conducted participating the EUREKA workshop.

Twenty two questionnaires were returned during the period of April 2007 in two rounds acoording to the proposed Delphi method.

\subsection{Experts Selection}

The following criteria were devised in order to identify eligible participants for the present Delphi study:

1. Practitioners who have extensive working experience in the construction industry in Greece.

2. Experts should be involved in the management of construction projects in Greece.

3. Experts should have a detailed knowledge of the whole construction process. A list of the panel members and their type of occupation are shown in Table 1.

\begin{tabular}{|l|c|}
\hline \multicolumn{1}{|c|}{ Profession of the experts } & Number of experts \\
\hline Academics & 4 \\
\hline Architects & 5 \\
\hline Construction engineers & 7 \\
\hline Contractors-developers & 4 \\
\hline
\end{tabular}


The Role of Adaptive Environmental Management in Sustainable Development

\begin{tabular}{|l|c|}
\hline Economists & 2 \\
\hline Total & 22 \\
\hline
\end{tabular}

Table 1. Delphi experts

\subsection{First and Second Round Questions}

As mentioned above the Delphi method adopted in this study consisted of the following two rounds.

In the questionnaire of first round there is an introductory text regarding the purpose of this research, such as:

"...Thank you for being willing to complete the following questionnaire disseminated through the internet, which is being carried out for the research conducted in terms of the paper "Assessment of the economical benefits of sustainable construction in Greece. ............ in this matter the questionnaire sent to you below is an effort of scientific communication process trough Delphi tecnique which tries to highlight your opinion on the subject of the economic benefits of Sustainable Construction. The survey is based on the Delphi principles is fully anonymous and will be used only in scientific purposes. Please fill the information below (tick the appropriate boxes) and send it as a reply to our internet message"

Q1a. Are you aware of the economic benefits of sustainable construction during the project life cycle?

Q1b. If yes, did you manage to adopt sustainable development issues in construction practice?

Q2. What is your involvement in the projects of your organization?

Q3. According to your experience and in the basis of international literature what are the main economic benefits of sustainable construction? Please fill bellow.

In Table 2 the results of first round of the Delphi questionnaire sent via email to the panel experts (Table 2)

\begin{tabular}{|c|c|c|}
\hline & YES & NO \\
\hline Q1a & 22 & 2 \\
\hline Q1b & 13 & 10 \\
\hline
\end{tabular}

Table 2. Awareness and adoption of economic benefits in sustainable construction

In Table 3 the Participant's involvement in the projects are presented

\begin{tabular}{|c|c|c|c|}
\hline Director & Manager & Staff & Consultant \\
\hline 4 & 8 & 6 & 4 \\
\hline
\end{tabular}

Table 3. Participant's involvement in the projects

In Table 4 the common and not common economic benefits on Sustainable construction are tabulated. 


\begin{tabular}{|l|l|}
\hline 1 & Reduce energy usage \\
\hline 2 & Protection natural / social environnent \\
\hline 3 & Providing healthy comfortable living environment \\
\hline 4 & Success for developers and occupiers \\
\hline 5 & Building innovation management/technologies/policy \\
\hline
\end{tabular}

Table 4. List of the main economic benefits on Sustainable construction

The second round questionnaire consisting of 4 questions was sent out in March 2007 via email to the experts and was collected by the end of May 2007. At this stage, most of the experts had reconsidered and made adjustments to their score. The questionnaire refers to the drivers for change that have emerged as a result of the international and national construction industry's response to sustainability. The final drivers of change selected for consideration are presented in Table 2. Twenty two (22) questionnaires were returned, representing $66 \%$ of the issued questionnaires and these were used in the analysis presented in the following section. The questionnaire refers to the assessment of the economic benefits of sustainable construction that have emerged as a result of the international and national construction industry's response to sustainable construction. The challenges selected for consideration are those presented in Table 1. Persons employed in target population firms, organizations/authorities were asked to answer the following questions:

Question 4. In what phase of Life Cycle Assessment (LCA) do you believe that sustainable construction adopted in your field is more economical than standard practice? During the design phase; During the construction phase; During operation maintenance phase; During the demolition phase

Question 5. How the sustainable construction adopted in your field is compared over the entire project life cycle to the standard practices? More economical; Equally economical; Less economical.

Question 6. How are the economic benefits of sustainable construction prioritized?

(Please use the numbers 1 to 4 in order to declare preference)

Reduce energy usage; Protection of natural and social environment; Providing healthy and comfortable living environment; Success for developers and occupiers; Building innovation technologies.

Question 7. Did you realize economic advantages in the future of sustainable construction? If so how in what is the most important factor? Efficiency/Renewable Energy issues; Reuse/Recycle Water conservation; Conservation Materials and Techniques; Waste management.

In Table 5 the phase of LCA economic benefits were significant in sustainable construction are presented.

\begin{tabular}{|l|l|l|}
\hline & Votes & Rank \\
\hline Design & 10 & 1 \\
\hline Operation Maintenance & 7 & 2 \\
\hline Construction & 3 & 3 \\
\hline Demolition & 2 & 4 \\
\hline
\end{tabular}

Table 5. Phase of LCA adoption of sustainable construction 
The Role of Adaptive Environmental Management in Sustainable Development Case Study Assessing the Economical Benefits of Sustainable Construction in Greece

In Table 6 the question How the sustainable construction adopted in your field is compared over the entire project life cycle to the standard practices? in terms of three scales More economical; Equally economical; Less economical is presented.

\begin{tabular}{|c|c|c|c|c|c|c|}
\hline & $\begin{array}{c}\text { More } \\
\text { economical }\end{array}$ & Rank & $\begin{array}{c}\text { Equally } \\
\text { economical }\end{array}$ & Rank & $\begin{array}{c}\text { Less } \\
\text { economical }\end{array}$ & Rank \\
\hline votes & 19 & 1 & 2 & 2 & 1 & 3 \\
\hline
\end{tabular}

In Table 7 the prioritization in terms of the importance (scale 1 to 10) of the economic benefits in sustainable construction is presented.

\begin{tabular}{|l|l|c|c|c|c|c|c|c|}
\hline & Economic benefits (priority selection) & 1 st & 2nd & 3 st & 4 th & 5 th & final ranking \\
\hline 1 & Reduce energy usage, REU & 10 & 2 & 0 & 1 & 0 & 1 \\
\hline 2 & Protection natural/ social environment, NSE & 2 & 3 & 6 & 0 & 1 & 3 \\
\hline 3 & $\begin{array}{l}\text { Providing healthy comfortable living } \\
\text { environment, HLE }\end{array}$ & 1 & 5 & 4 & 1 & 2 & 4 \\
\hline 4 & $\begin{array}{l}\text { Success for developers and } \\
\text { occupiers, SDO }\end{array}$ & 0 & 2 & 0 & 6 & 7 & 5 \\
\hline 5 & $\begin{array}{l}\text { Building innovation } \\
\text { management/technologies/policy BIM }\end{array}$ & 5 & 6 & 3 & 2 & 2 & 2 \\
\hline
\end{tabular}

Table 7. Importance degree of the economic benefits in sustainable construction (prioritized)

This is best illustrated in Figure 2 where these factors are presented in terms of their rank (1st $\left.2^{\text {nd }} ..\right)$.

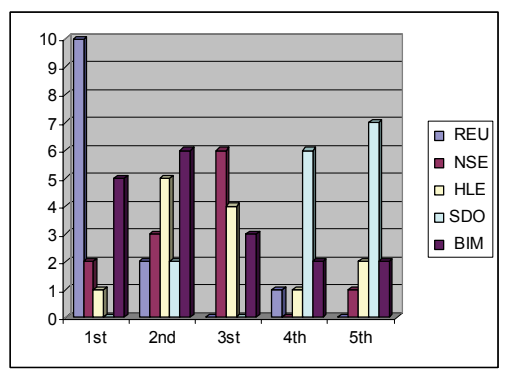

Fig. 2. Prioritization of the economic benefits of sustainable construction

The second round shows the results of the experts perception on which phase (design, construction, maintenance and demolition) was more economical than the standard practice. Table 5 presents the perception of the experts on how the sustainable construction adopted in their field is compared over the entire project life cycle to the standard practices. Table 8 presents the prioritization of the economical benefits in terms reduction of energy usage Protection of natural and social environment, Providing healthy and comfortable living environment and success for developers and occupiers. As can be seen reduction of energy ranks first (voted by 10 participants) followed by protection and natural and social environment (voted by 2 participants) while only one voter has selected providing healthy The majority of the participants $93 \%$ are aware of the benefits of sustainable construction during the project life cycle and most of them (64\%) have managed to adopt sustainable development issues in construction practice. 
The novelty of this approach than the classical Delphi method is the possibility of feedback between stages where the factors or actions may be modified to include changes in the research. For instance question 7 can be reconsidered to the participants as follows

Q7. From the following factors Efficiency/Renewable Energy issues; Reuse/Recycle Water conservation; Conservation Materials and Techniques; Waste management what is the most important factor?

The same information can be used to state the factors affecting the futures of sustainable construction

\begin{tabular}{|l|c|c|}
\hline & votes & Rank \\
\hline Efficiency/renewable Energy Issues & 10 & 1 \\
\hline Conservation Material and Techniques & 5 & 2 \\
\hline Waste Managemet & 4 & 3 \\
\hline Reuse/Recycle Water Conservation & 3 & 4 \\
\hline
\end{tabular}

Table 8. Factors affecting the futures of sustainable construction

\section{Conclusion}

Action research is seen as a process which both helps the development of this social capital, and provides lessons into how it can be expanded. Moreover, building capacity for the use of participatory learning processes should be part of the method, that capacity cannot be assumed to be there. The role of eadaptive environmental management for participation and measuring process success is highlighted Finally the research points to the need to draw out lessons from across action research case studies, and suggests some challenges for action research to help in large-scale collaborative learning.

A version of Delphi study embracing a development paradigm that places people at the centre and seeks to empower stakeholders to influence and share control over development initiatives and the decisions which affect them. Even as macroeconomic policies and trends continue to shape sustainable development opportunities, the move away from centralised planning by governments is requiring $R \& D$ initiatives to work towards empowering communities to deal with their own needs. In this regard, the challenge for researchers is to work with communities and undertake inquiries that begin with the search for solutions to social (community) problems -- placing an emphasis on problem context and identification.

The outlined version of Delphi, however, it is suggested that this should be implemented in an environment characterized environment by high social capital.

Because one of the main issues related to establishing such a collaborative approach within the wider social and institutional contexts of catchments and regions is one of implementation, an action research approach provides an appropriate methodology. This is directly applicable to the study of how individuals and groups design and implement action in relation to one another.

What is significant about case study is not that it has resulted in a regional adaptive management approach to sustainable construction but those involved (researchers, managers and local government staff representatives) have learnt more about the processes and issues involved in working together and sharing information, and continue to seek ways to implement adaptive management. In doing so. a questionnaire survey based on the Delphi method was conducted in order to assess the benefits of sustainable construction. The majority 
of the participants $93 \%$ are aware of the benefits of sustainable construction during the project life cycle and most of them (64\%) have managed to adopt sustainable development issues in construction practice. Also the majority of the participants believe that sustainable construction is overall more economical than standard practice specially is more economical at the operation phase of LCA (Life Cycle Assessment) and important to be adopted at the design phase. By using feedback in the process the factor Reduce energy usage, finally is ranking first between the economic benefits of sustainable construction followed by Protection of natural and social environment, and Providing healthy and comfortable living environment. The competitive advantages in the future of sustainable construction are realized by the majority of the participants and the most important factor for this is assigned to the Efficiency/Renewable Energy issues followed by Conservation Materials and Techniques.

Future areas of activity with the potential to leverage improved information flows within environmental research and management are suggested as improving participation and the use of local knowledge in the research process improving the dissemination and use of this knowledge in the wider community through improved networking and collaboration; and supporting these approaches through participatory monitoring and evaluation. Moreover, there is an increasing realisation that new sources of 'expert knowledge' and databases are needed to identify persistent sustainable management practices more clearly. In many cases, the knowledge that is required about the past and present state and about the relationships between social and environmental systems is held within local communities and implementation and policy agencies. Accordingly, it follows that the task of organising information to understand better the links between sustainable management is needed, social realities dynamics should be a collaborative venture between research scientists and the different stakeholders involved.

\section{References}

Adnan, H. and Morledge, R. (2003) "Application of Delphi Method on Critical Success Factors in Joint Venture Projects in Malaysian Construction Industry" Proceedings CITCII Conference, held in Hong Kong 10-12 December 2003. Bawden, R.J. (1987) Learning systems and technological change. Proceedings of the

Bossink B.A. (2002) Dutch public-private strategy for innovation in sustainable construction Construction Management and Economics, Volume 20, Number 7, 1:633-642.

Brundtland report, 1987

Beemans, P. (1996) Culture, spirituality and economic development: Foreword in Culture, spirituality, and economic development: Opening a dialogue.(Ryan, W.F.) Ottawa, Canada: International Development Research Centre. (Available from <http://www.idrc.ca/books/focus/782/782fore.html> Accessed 4 October 2000).

Checkland, P.B. (1981a) Systems thinking, systems practice. Chichester, UK: Wiley.

Checkland, P.B. (1981b) Towards a systems-based methodology for real-world problem solving. Pp. 288-314 in Systems behaviour 3rd edition (Ed.: Open Systems Group)London: Harper and Row.

Checkland, P. (1985a) From optimizing to learning: A development of systems thinking for the 1990s. Journal of the Operational Research Society 36:757-767.

Checkland, P. (1985b) Achieving 'desirable and feasible' change: An application of soft systems methodology. Journal of the Operational Research Society 36: 821-831.

Cosmao, V. (1984) Un monde en development! Guide de reflexion. Paris: Editions Ouvrieres.

Bikas, D. and Milonas, S. (1998) Sustainable construction in Greece. Web: http://bativille.cstb.fr/CIB_Reports_pdf/gr.pdf 
Cabanis, K (2002) Computer-Related Technology Use By Counselors in the New Millennium- A Delphi Study, Journal of Technology in Counseling, Vol. 2-2, pp. 2334 Web: http://jtc.colstate.edu/Vol2_2/cabanis/cabanis.htm

Cabanis, K. (2001). Counseling and computer technology in the new Millennium-An Internet Delphi study [Online dissertation]. Retrieved May 4, 2001, from the Virginia Tech Digital Library and Archives on the World Wide Web: http:/ / scholar.lib.vt.edu/theses/available/etd-03072001-175713/

Corotis, R. Fox, R. Harris (1981) Delphi Methods: theory and design load application. Journal of the Structural Division, ASCE, 107 (6), 1095-105

Dahlberg, K.A. (1979) Beyond the green revolution. New York: Plenum Press.

Dahlberg, K.A. (1991) Sustainable agriculture - fad or harbinger? BioScience 41: 337-340.

DETR, (1999), Sustainable Development Education Panel: First Annual Report 1998, HMSO, London.

Dickey, J \& Watts, T (1978) Analytic Techniques in Urban and Regional Planning, McGrawHill, New York.

Helmer, O. (1966). Social technology. New York:

Helmer, O. (1970). Long-range forecasting: Role and methods. Paper presented at the Conference on Forecasting the Future, Harrogate, England.

Hill, R., and Bowen, P., (1997) Sustainable construction: Principles and a framework for attainment, Construction Management and Economics 15, 223 -239

Khalfan, M. M. A., Bouchlaghem, N. M., Anumba, C. J., \& Carrillo, P. M. (2003),

Knowledge Management for Sustainable Construction: The C-SanD Project, 2003 Construction Research Congress, held in Honolulu, Hawaii on 19 - 21 March 2003,

Linstone, H and Turoff, M (1975) The Delphi Method: Techniques and Application, Addison, Wesley, Reading, MA, pp. 3-12

Manoliadis, O. and Tsolas, I. (2004) "Sustainability initiatives undertaken by EU in procurement policies and practices awarding construction products", 18th IPMA World Congress on Project Management 19-20 June 2004, IPMA -FOVOSZ, Budapest.

Manoliadis O. and Vatalis K. (2007). Assessment of the Economic Benefits of Sustainable Construction Ecosummit Conference Sanghai 12-18 May 2007.

Ofori, G. (1998). "Sustainable construction: principles and a framework for attainment comment," Construction Management \& Economics, Taylor and Francis 16(2):141-145

Outhred, G.P (2001) The Delphi Method: A Demonstration of its Use for Specific Research Types, Proceeding of the RICS Foundation, Construction \& Building

Robinson,.B.L (1991) "Delphi Technology for economic impact assessment". Journal of Transportation Engineering, 117(3)

Rowe, G. and Wright, G. (1999) "The Delphi Technique as a Forecasting Tool: Issues and Analysis", International Journal of Forecasting, Volume 15, Pages 353-37

Sha, K., X. Deng, C. Cui. 2000. "Sustainable construction in China: status duo and trends", Building Research \& Information, 28(1): 59-66

Uher T.E., (1999) Absolute Indicators of Sustainable Construction RICS Research Foundation available at http://www.rics.org/NR/rdonlyres/5A12CAFF-13FD-4D31-9C62D5DC1958A745/0/ absoluteindicators of_sustainableconstruction_19990901.pdf

Vanegas, J. A. and Pearce, A., R. Drivers for Change (2006): An Organizational Perspective on Sustainable Construction Web: www.maven.gtri.gatech.edu/sfi/sustainables/pdf/ RCP/RCP001. PDF 


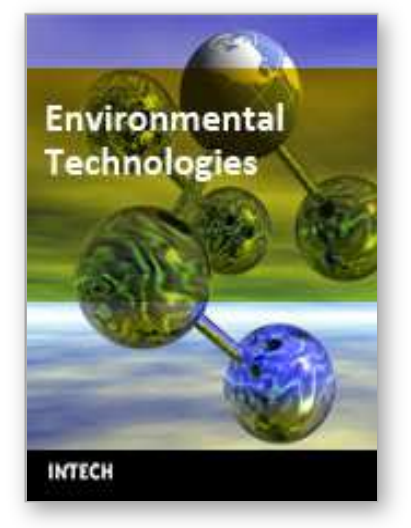

\author{
Environmental Technologies \\ Edited by E. Burcu Ozkaraova Gungor
}

ISBN 978-3-902613-10-3

Hard cover, 268 pages

Publisher I-Tech Education and Publishing

Published online 01, January, 2008

Published in print edition January, 2008

This book on Environmental Technology takes a look at issues such as air, soil and noise pollution problems, environmental quality assessment, monitoring, modelling and risk as- sessment, environmental health impact assessment, environmental management and envi- ronmental technology development. It represents institutional arrangements, financial mechanisms and some sustainable technologies. The user can always count on finding both introductory material and more specific material based on national interests and problems. The user will also find ample references at the end of each chapter, if additional information is required. For additional questions or comments the user is encouraged to contact the author.

\title{
How to reference
}

In order to correctly reference this scholarly work, feel free to copy and paste the following:

Odysseus G. Manoliadis (2008). The Role of Adaptive Environmental Management in Sustainable Development Case Study Assessing the Economical Benefits of Sustainable Construction in Greece, Environmental Technologies, E. Burcu Ozkaraova Gungor (Ed.), ISBN: 978-3-902613-10-3, InTech, Available from:

http://www.intechopen.com/books/environmental_technologies/the_role_of_adaptive_environmental_manage ment_in_sustainable_development_case_study_assessing_the_ec

\section{INTECH}

open science | open minds

\author{
InTech Europe \\ University Campus STeP Ri \\ Slavka Krautzeka 83/A \\ 51000 Rijeka, Croatia \\ Phone: +385 (51) 770447 \\ Fax: +385 (51) 686166 \\ www.intechopen.com
}

\author{
InTech China \\ Unit 405, Office Block, Hotel Equatorial Shanghai \\ No.65, Yan An Road (West), Shanghai, 200040, China \\ 中国上海市延安西路65号上海国际贵都大饭店办公楼 405 单元 \\ Phone: +86-21-62489820 \\ Fax: +86-21-62489821
}


(C) 2008 The Author(s). Licensee IntechOpen. This chapter is distributed under the terms of the Creative Commons Attribution-NonCommercialShareAlike-3.0 License, which permits use, distribution and reproduction for non-commercial purposes, provided the original is properly cited and derivative works building on this content are distributed under the same license. 